\title{
Decriminalize payment of donors and surrogates, says MP
}

A

Member of Parliament is calling for full commercialization in the trade of eggs, sperm and contract pregnancy. Anthony Housefather, the Liberal MP from Mount Royal, Que., who was recently elected chair of the House of Commons Standing Committee on Justice and Human Rights, says it's time to get rid of the parts of the law that criminalize paying a gamete donor or surrogate. The committee has identified the issue as one of three topics for future study.

The Assisted Human Reproduction Act became law in 2004 following a lengthy Royal Commission and years of political wrangling. One of the more controversial parts of the law says that anyone found to be paying gamete donors or surrogates, or taking money to arrange these transactions, can be subject to fines of up to $\$ 500000$ or ten years in prison. Only one person has ever been convicted under the law, but violation is widespread.

In an op-ed in the Montreal Gazette on Mar. 8, Housefather argued that "we must strike the provisions of the Assisted Human Reproduction Act banning payment for donors and surrogates and adopt new regulations that clarify the rules for everybody."

Drafters of the law argued at the time that offering money to women for their eggs and use of their wombs would be too exploitive; instead, only expenses are allowed. The ban on payment is in keeping with policies on organ transplant and blood products. "The human body should not be in the marketplace," says Françoise Baylis, a bioethicist at Dalhousie University in Halifax. If you can pay for an egg, she asks, why not a kidney that could save a life?

In addition, people born through traded gametes testified that paying biological progenitors turns offspring into commercial goods. Olivia Pratten, who was conceived through anonymous sperm donation and who fought a legal

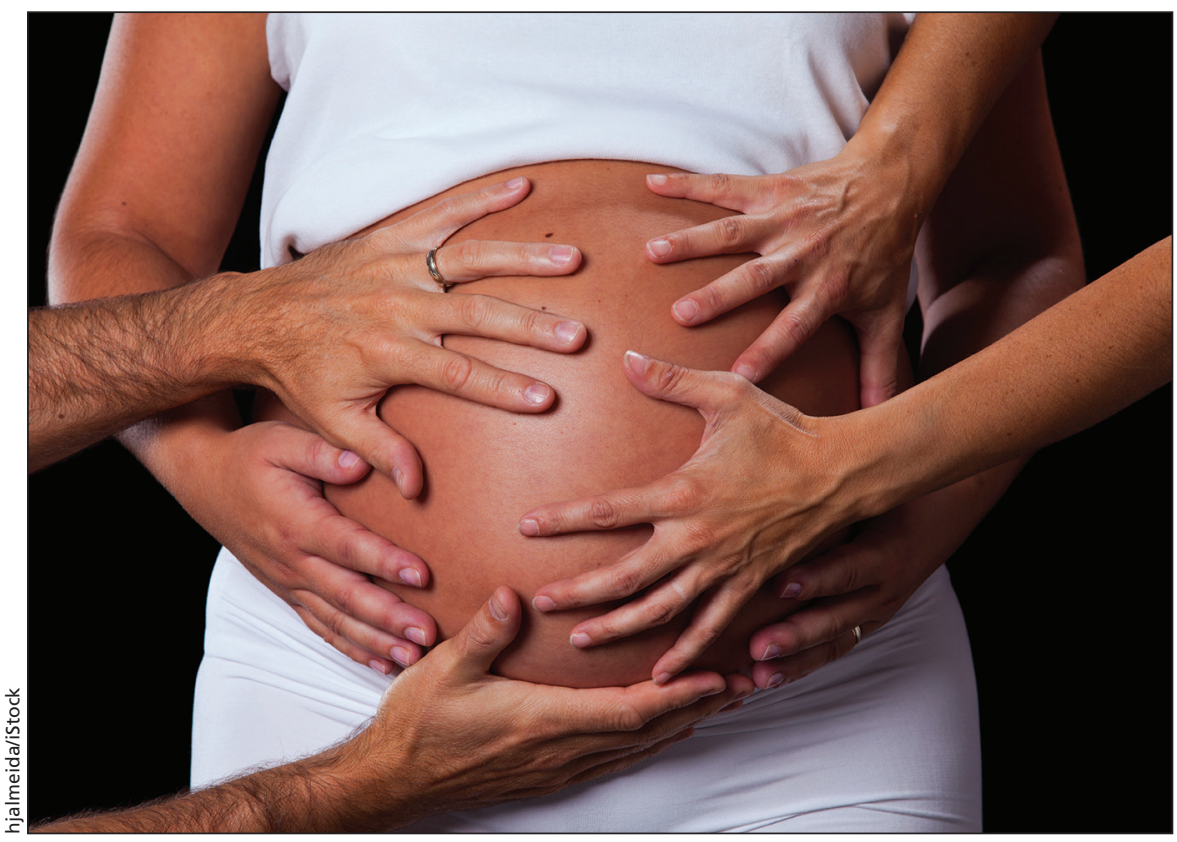

Opponents to paying surrogates say it turns offspring into commercial goods.

battle for the right to know her donor's identity, stands by that view today: "The minute money is exchanged, the intended parents become 'the consumers', the donor or surrogate is the 'seller', which means the child is a "product'."

But Housefather says he believes the majority of Canadians would disagree. "We have to recognize that Canadians' views on this issue have evolved," he says. He says we need to permit surrogates, egg donors and sperm donors to be compensated for their services. "The market should be able to function."

Art Leader, an Ottawa fertility physician who has been involved in the debate over regulation since the 1980 s, agrees the law needs to be updated. "I've always disagreed with the criminal prohibitions. There's no other medical intervention where the state imposes criminal sanctions and federal oversight." He believes doctors can self-regulate.

Less optimistic about self-regulation is Erin Nelson, a health care ethics and law professor at the University of Alberta in Edmonton. She thinks an independent, arms-length agency should regulate. Like Housefather, Nelson laments the fact that uncertainty about Canada's law drives many parents out of the country. Not only does that create big obstacles when families try to return, but it means we are just "shipping our ethical problems offshore," she says.

Health Canada's Sean Upton wrote in an email that the department remains committed to the tenets of the act, but has been working with stakeholders to clarify what constitutes acceptable expenses for surrogates.

There is little agreement on these issues internationally. Many US states allow unlimited compensation to donors or surrogates; the United Kingdom regulates strictly and allows capped compensation; many European states forbid surrogacy, egg donation or both, even when altruistic.

"My first plea," says Housefather, "is let's be talking about this." - Alison Motluk, Toronto, Ont.

CMAJ 2016. DOI:10.1503/cmaj.109-5253 